Abstracta Iranica Abstracta Iranica

Revue bibliographique pour le domaine irano-aryen

Volume 40-41 | 2019

Comptes rendus des publications de 2017-2018

\title{
Rezā Kalāni. Multiple Identification Alternatives for Two Sassanid Equestrians on Fìrūzābād I Relief: A Heraldic Approach
}

\section{Rika Gyselen}

\section{(2) OpenEdition \\ Journals}

Édition électronique

URL : http://journals.openedition.org/abstractairanica/50242

DOI : $10.4000 /$ abstractairanica. 50242

ISBN : 1961-960X

ISSN : 1961-960X

Éditeur :

CNRS (UMR 7528 Mondes iraniens et indiens), Éditions de l'IFRI

\section{Référence électronique}

Rika Gyselen, «Rezā Kalāni. Multiple Identification Alternatives for Two Sassanid Equestrians on

Firūzābād I Relief: A Heraldic Approach », Abstracta Iranica [En ligne], Volume 40-41 | 2019, document 60, mis en ligne le 30 décembre 2019, consulté le 16 avril 2021. URL : http://journals.openedition.org/ abstractairanica/50242 ; DOI : https://doi.org/10.4000/abstractairanica.50242

Ce document a été généré automatiquement le 16 avril 2021

Tous droits réservés 


\title{
Rezā Kalāni. Multiple Identification Alternatives for Two Sassanid Equestrians on Fìrūzābād I Relief: A Heraldic Approach
}

\author{
Rika Gyselen
}

\section{RÉFÉRENCE}

Rezā Kalāni. Multiple Identification Alternatives for Two Sassanid Equestrians on Fīrūzābād I Relief: A Heraldic Approach. Téhéran: Tarikh Negar Monthly, 2017, ISBN

978-600-04-9140-6

1 Dans ce fascicule de 50 pages, l'auteur examine l'identification des deuxième et troisième personnages sassanides sur le relief équestre de Fīrūzābād I. Que le deuxième personnage sur le relief de Fīrūzābād I ne soit pas Šābuhr I ${ }^{\text {er }}$ reste à prouver. De toute manière, des arguments numismatiques prouvent qu'il s'agit bien d'un prince héritier. Quant au troisième personnage, souvent désigné dans la littérature sous le terme « page ", l'A. propose de l'identifier soit à Abursām, le 'vizir' d'Ardashir I Ir, soit au chef de la noble famille Suren.

2 Une discussion intéressante, mais désormais un peu dépassée par l'identification récente du petit buste sur les monnaies d'Ardašìr I ${ }^{\text {er }}$ à deux bustes (N. Schindel, «A new look at the Thronfolgerprägungen of the Sasanian king Ardashir: Goodbye to Shapur I, welcome to Ardashir Sakanshah », The Numismatic Chronicle, 179, 2016, p. 227-240, pl. 27 - Voir le cr AbsIr 37-39, rubrique 3.2.3, $\mathrm{n}^{\circ} 82$ ). 


\section{AUTEURS}

\section{RIKA GYSELEN}

CNRS, Mondes iranien et indien 